\title{
HAKIKAT BELAJAR DALAM ISTILAH TA'ALLAMA, DARASA, THALABA PERSPEKTIF PENDIDIKAN AGAMA ISLAM
}

\author{
Musaddad Harahap \\ Fakultas Agama Islam, Universitas Islam Riau, Pekanbaru, Propinsi Riau, Indonesia. \\ e-mail: musaddadharahap@fis.uir.ac.id
}

\begin{abstract}
ABSTRAK
Arus perkembangan ilmu pendidikan telah banyak menciptakan konsep-konsep belajar. Tidak sedikit umat Islam yang terlena dengan penemuan-penemuan itu. Satu sisi memang patut diapresiasi sekaligus dicermati, tetapi pada sisi lain umat Islam juga harus mengarahkan perhatiannya untuk melakukan kajian tentang konsep belajar dalam Islam itu sendiri. Belajar dalam Islam adalah sesuatu yang penting sehingga setiap muslim diwajibkan untuk belajar. Islam memandang belajar bukan hanya untuk orang dewasa, tetapi Islam mengajarkan bahwa belajar sudah dimulai dari buaian sampai ke liang lahat. Dengan metode studi kepustakaan maka ditemukan belajar dalam Islam merupakan tema yang sangat sentral. Istilah belajar yang digunakan dalam sumber ajaran Islam (Al-Qur'an dan Sunnah) paling tidak ada tiga, yaitu ta'allama, darasa, dan thalaba. Dari ketiga istilah tersebut dapat dipahami bahwa belajar dalam Islam adalah aktivitas yang dilakukan secara serius dan konsentrasi, muncul dari niat yang tulus, dilakukan secara kontinu. Belajar juga harus ditempuh melalui guru, sementara seorang guru hendaknya memperhatikan kesiapan pelajar dalam menerima ilmu pengetahuan. Berhasil atau tidaknya belajar sangat ditentukan oleh bagaimana keterlibatan fisik dan psikis manusia. Tujuan belajar yang paling penting ditinjau dari perspektif pendidikan Islam adalah pengamalan untuk meraih ridho Allah swt.
\end{abstract}

Kata Kunci: Hakikat, Belajar, Ta'allama, Darasa, Thalaba.

\section{ABSTRACT}

The current development of educational science has created many learning concepts. Some of Muslims has been ignored about these findings. One side deserves appreciation at the same time, but on the other side Muslims must directing their attention to study the concept of learning process in Islam itself. With the Literature Study or Library Research Method, learning process in Islam is a very important theme. The term learning process has been used in the sources of Islamic teachings (Al-Qur'an and Sunnah) there are at least three terms, namely ta'allama, darasa, and thalaba. From these three terms, it can be understand that learning process in Islam is an activity that is carried out seriously and need concentration, arising from a sincere intention, and carried out continuously. Learning process must also be pursued through the teacher, while a teacher should giving the attention to the readiness of students in receiving knowledge. Success or failure of learning process is largely determined by how physical and psychological involvement from the student as human being. The most important learning purpose according to the perspective of Islamic education is the practice of achieving the blessings from Allah swt.

Keywords: Essence, Learning, Ta'allama, Darasa, Thalaba.

\begin{tabular}{l|c|c|c}
\hline First Received: & Revised: & Accepted: & Published: \\
12 October 2019 & 15 October 2019 & 16 October 2019 & 16 October 2019 \\
\hline
\end{tabular}




\section{PENDAHULUAN}

Perjalanan umat Islam sampai saat ini $(1441 \mathrm{H})$ telah mengalami proses yang cukup panjang. Perubahan yang terjadi dalam kehidupan umat Islam merupakan miniatur dari karya besar dari hasil proses pembelajaran leluhur di masa lalu. Secara logika tidak mungkin terbentuk kehidupan yang sangat plural dan kompleks adanya upaya-upaya serius yang mendahuluinya. Meskipun demikian, perpindahan estafet kehidupan umat selalu mengalami pasang surut. Ada kalanya perubahan itu positif, tetapi pada masa tertentu tidak jarang juga mengalami kemunduran.

Peradaban Islam dalam sejarah pernah mengalami kejayaan. Pada masa itu, peradaban Islam adalah sumber ilmu pengetahuan. Terhitung mulai abad XXVII Masehi umat Islam pernah mendominasi. Kemampuan umat Islam mendominasi proses pembelajaran dan pengembangan ilmu pengetahuan didorong oleh pemahaman yang sangat baik terhadap sumber hukum Islam itu sendiri (Barni, 2011: 9-10).

Bila ditelaah ke belakang, keberhasilan Islam dalam pendidikan memiliki perjuangan yang cukup berat. Pada awalnya tradisi belajar itu dirintis oleh Nabi Muhammad saw., kemudian tumbuh dan berkembang di masa khulafaur rasyidin, barulah puncaknya terjadi pada masa bani Abbasiyah. Adapun faktor utama puncak kejayaan yang pernah dicapai umat Islam ini tentu tidak bisa dilepaskan dari proses pembelajaran yang pernah dilakukan. Dengan proses pembelajaran yang baik maka lahirlah banyak ulama dan ilmuwan dengan karyakarya monumental yang luar biasa (Wahyuningsih, 2014: 109). Selain mereka ilmuwan, mereka juga agamawan dan ahli ibadah.

Berasal dari pembelajaran yang baik pula, para ilmuwan muslim mampu meletakkan tonggak dasar ilmu pengetahuan dengan karakteristik khas dan secara fundamental berbeda jauh dengan temuan-temuan ilmuwan sebelumnya terutama di masa Yunani Kuno. Perbedaan itu, misalnya, tampak dari landasan, sumber, sarana, dan metodologinya. Pembelajaran yang dilakukan umat Islam tidak pernah lepas dari al-Qur'ān dan Sunnah; kemudian sumber yang digunakan bukan hanya alam fisik tetapi juga mencakup metafisik; pembelajaran yang dilakukan pun menggunakan indera, akal, dan hati/intuitif. Jadi, cakupan pembelajaran dalam Islam sangat luas, tidak hanya menyangkut persoalanpersoalan duniawi atau yang bersifat materil, namun juga berkaitan dengan 
permasalahan-permasalahan

ukhrawi

(Kosim, 2008: 121). Dengan demikian, belajar dalam Islam benar-benar menjadi instrumen yang sudah teruji sehingga mampu untuk mengantarkan agama Islam itu menjadi rahmat bagi seluruh alam. Atas dasar itulah kemudian Allah swt. mengangkat derajat orang yang berilmu, sebagaimana disebut dalam Al-Qur'an surah Al-Mujadalah ayat 11:

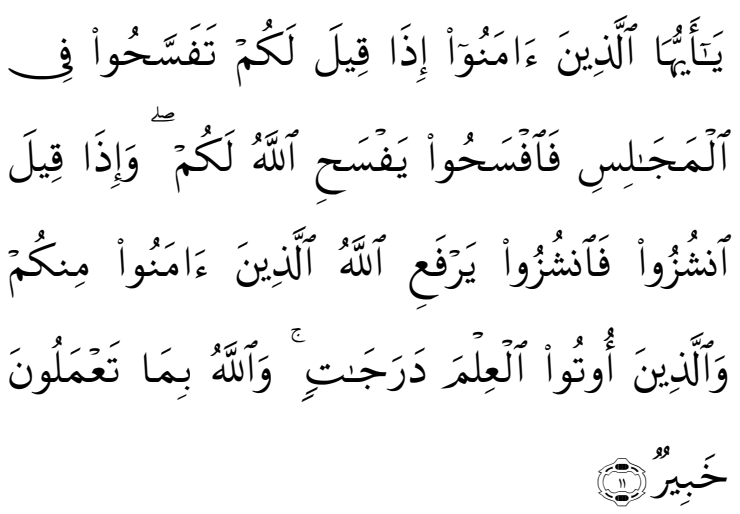

Artinya: Hai orang-orang beriman apabila kamu dikatakan kepadamu: "Berlapanglapanglah dalam majlis", Maka lapangkanlah niscaya Allah akan memberi kelapangan untukmu. dan apabila dikatakan: "Berdirilah kamu", Maka berdirilah, niscaya Allah akan meninggikan orang-orang yang beriman di antaramu dan orang-orang yang diberi ilmu pengetahuan beberapa derajat. dan Allah Maha mengetahui apa yang kamu kerjakan.

Dalam keyakinan umat Islam, berilmu adalah pemberian Tuhan. Keyakinan ini mutlak adanya karena sumber segala ilmu adalah Tuhan yang Maha 'Alim. Ilmu sebagai pemberian Tuhan didapatkan melalui berbagai cara, salah satu di antaranya belajar (nazhari). Pada umumya manusia memperoleh ilmu melalui belajar (nazhari) tersebut, selebihnya ada pula yang mendapatkan ilmu dari Allah melalui wahyu (khusus para Nabi dan Rasul), dan ilmu kasyaf atau ladunni (khusus orang-orang pilihan yang bersih hatinya). Dengan begitu wajar apabila Allah swt. meninggikan derajat orang berilmu karena mereka telah berupaya untuk mengoptimalkan anugerah potensi (sam'a, abshar, qalb, dan aql) yang diberikan pemilik ilmu tersebut. Ketika manusia telah mampu untuk mengoptimalkan potensi yang dimilikinya dengan disertai amal-amal yang baik maka sangat mudah bagi Allah swt. untuk memberikan ilmu kepada hati mereka.

Dalam keyakinan Islam tidak ada yang mustahil bagi Allah karena manusia adalah ciptaan-Nya. Sesuatu yang diciptakan dalam akidah Islam adalah baharu sehingga manusia pada level ini sangat memungkinkan untuk berubah. Kemungkinan perubahan ini yang harus dioptimalkan dengan belajar sehingga manusia benar-benar sampai kepada maqam yang terbaik di sisi Allah swt. (Harahap, 2017: 148). Hal inilah yang telah dipraktekkan oleh para ulama-ulama masyhur sehingga mereka mendapat 
pujian dari Allah swt. seperti terdapat dalam surah Fathir ayat 28:

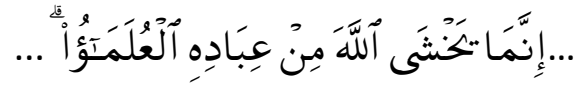

Artinya: “...Sesungguhnya yang takut kepada Allah di antara hamba-hamba-Nya, hanyalah ulama...".

Kata 'ulama bentuk jamak dari 'alim yang berasal dari kata 'alima yang memiliki arti orang yang memiliki ilmu, sedangkan kata 'alima sendiri bermakna mengecap atau memberi tanda (Munawwir, 1997: 965). Jadi, ulama pada ayat ini digolongkan kepada orang yang memiliki ilmu pengetahuan yang luas tentang keagungan Allah swt. Kemudian jika ditelusuri lebih lanjut kata 'alima yang menjadi asal kata ulama ternyata seakar dengan kata 'alam (dunia), berarti ulama adalah ilmuwan yang paham tentang hakikat dunia (Susanti, 2018: 103). Jadi, ulama merupakan manusia yang dianugerahi ilmu agama dan hakikat ilmu dunia yang dengannya mereka semakin takut dan mencintai Allah swt. Jadi dapat dipahami untuk mengenali keagungan Allah swt. manusia harus berilmu, sedangkan ilmu itu sendiri didapatkan melalui proses belajar yang baik.

Dengan demikian belajar memiliki posisi yang sangat penting dalam ajaran Islam. Nabi Muhammad saw. bersabda:

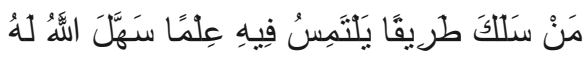

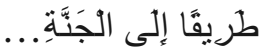

Artinya: "Barangsiapa menempuh jalan untuk mencari ilmu maka Allah akan mudahkan baginya di antara jalan menuju surga...”. (H.R. At-Tarmidzi)

Belajar dalam pendidikan Islam bukanlah aktivitas formalitas saja, tetapi belajar haruslah menampakkan hasil yang memungkinkan untuk diterapkan dan diamalkan. Puncak dari belajar adalah berilmu, sedangkan berilmu ditempatkan lebih utama dibandingkan dengan ahli ibadah. Hal ini dapat dipahami dari lanjutan hadits sebelumnya, yaitu:

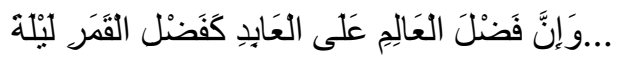

Artinya: “...Sesungguhnya keutamaan orang yang berilmu dibanding ahli ibadah adalah seperti perbandingan bulan di malam badar dari bintang-bintang lainnya." (H.R. Abud Daud).

Mengingat pentingnya penguasaan ilmu dalam Islam dibanding amal, ulama besar Ibnu Ruslan pernah berkata, yaitu:

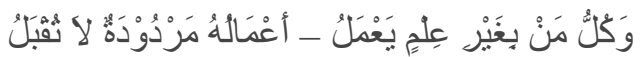

Artinya: Setiap yang beramal tanpa ilmu, maka amalannya ditolak tidak diterima.

Begitulah pentingnya belajar dalam Islam. Jadi belajar hakikatnya harus ada perubahan signifikan untuk mencapai kesempurnaan. Meskipun begitu, belajar bukanlah persoalan yang mudah, tetapi belajar memiliki dimensi-dimensi yang 
sangat kompleks. Hal itu disebabkan karena belajar sangat penting. Kemudian para tokoh mencoba untuk menggunakan akal pikirannya dalam menemukan hakikat belajar. Misalnya para tokoh pendidikan kontemporer sering memaknai belajar sebagai proses perubahan tingkah laku diakibatkan adanya interaksi individu dengan lingkungan sekitarnya. Perubahan perilaku terhadap hasil belajar bersifat kontinu, fungsional, positif, aktif, dan terarah. Kemudian, keberhasilan proses belajar yang dilakukan tersebut dapat dilihat dari kesesuaian dengan tujuan awal belajar yang dilakukan. Bila tujuan belajar telah sesusai dengan perubahan tingkah laku maka dapatlah dikatakan bahwa guru telah berhasil memberikan pembelajaran (Pane dan Dasopang, 2017: 334). Selaras dengan pendapat tersebut belajar juga dipahami terjadi akibat adanya respon terhadap rangsangan dari lingkungan sekitar. Dengan rangsangan yang didapatkan maka terjadilah jenis-jenis interaksi tertentu secara internal di dalam otak (Gasong, 2018: 9).

Sesungguhnya banyak teori tentang belajar dan mengajar, prinsipnya setiap teori yang ada adalah bagian dari upaya untuk membekali manusia menghadapi kehidupan ke arah yang lebih baik. Secara teoretis, rumusan belajar biasanya muncul sangat tergantung dan ditentukan oleh falsafah hidup perumusnya, namun dalam Islam belajar tidak demikian. Belajar dalam Islam harus mengacu kepada prinsip-pripsip dasar sumber hukum Islam, yaitu Al-Qur'an Sunnah Nabi Muhammad saw. Jadi pendidikan Islam sangat konsisten dengan dua sumber tersebut. Dengan demikian dalam tulisan ini perlu kiranya diuraikan begaimana prinsipprinsip belajar dalam pendidikan Islam.

\section{METODE PENELITIAN}

Tulisan ini menggunakan jenis Penelitian Kepustakaan (Library Research), yaitu memanfaatkan perpustakaan untuk sumber kajian. Pemilihan jenis penelitian ini didasari oleh tiga hal utama. Pertama, bahwa data yang ingin dicari berkaitan dengan gejala-gejala ajaran agama Islam terkaitan dengan proses belajar dalam agama Islam. Kedua, studi pustaka ini sangat diperlukan untuk memahami gejala-gejala yang terjadi di lapangan terkait dengan esensi proses belajar itu sendiri, dan ketiga, penelitian kepustakaan merupakan metode yang yang diperbolehkan untuk menginput data-data termasuk data laporan penelitian, bukubuku, informasi, bahkan data empirik sekalipun. Jadi penelitian ini akan berupa untuk membaca, mencatat dan mengolah 
bahan-bahan yang dikumpulkan (Zed, 2008: 2-3).

Untuk mendapatkan data dalam penelitian ini, maka ada empat langkah yang dilakukan, yaitu sebagai berikut.

1. Menyiapkan alat-alat perlengkapan untuk mencatat semua bahan yang dibutuhkan selama penelitian.

2. Menyusun bibliografi kerja (bahan) yang dikategorikan menjadi bahan primer dan skunder.

3. Mengatur waktu seoptimal mungkin untuk memastikan selama penelitian konsentrasi tetap terjaga sehingga materi-materi yang dihimpun dapat diorganisir sebaik mungkin.

4. Membaca dan membuat catatan penelitian yang berguna untuk persiapan analisis sehingga dapat kesimpulan yang dapat dipertanggung jawabkan (Zed, 2008: 16-22).

Setelah bahan-bahan tentang hakikat belajar dalam pendidikan Islam (Al-Qur'an, Hadits, dan Ijtihad para Ulama) dikumpulkan maka dilakukan analisis data sehingga dengan penelitian ini dapat ditarik kesimpulan teoretis tentang hakikat belajar dalam perspektif pendidikan Islam. Adapun analisis data yang digunakan adalah analisis isi (content analysis), yaitu memperlakukan bahanbahan secara objektif dan sistematis sehingga akan mendapat inferensi valid dari teks-teks yang dijadikan sebagai sumber penelitian (Eriyanto, 2015: 15-16). Jadi semua referensi yang dikumpulkan untuk kebutuhan penelitian ini akan diperlakukan seobjektif mungkin untuk mendapat gambaran isi yang valid tanpa ada bias dan keberpihakan.

\section{HASIL DAN PEMBAHASAN}

\section{Hakikat Belajar dalam Istilah Ta'allama}

Dalam Islam belajar merupakan aktivitas yang tidak dapat dipisahkan dari kehidupan manusia. Dilihat dari istilah, belajar adalah menerima ilmu sebagai konsekuensi adanya pengajaran. Itulah sebabnya dalam tata bahasa Arab belajar itu disebut dengan ta'allama. Adapun asal kata ta'allama adalah 'alima yang berarti mengecap, memberi tanda (Munawwir, 1997: 965). Ta'allama juga sama dengan tahajjaba yang berarti terdidik (Munawwir, 1997: 996). Oleh karena itu, belajar adalah kegiatan yang akan meninggalkan tanda setelah orang melalui proses pembelajaran. Sama halnya dengan terdidik, yaitu orang yang sadar menerima pendidikan dari orang lain. Kesadaran dalam belajar merupakan syarat untuk sampai kepada konsentrasi belajar. 


\section{Dalam Al-Qur'an kata ta'allama} ini terulang dua kali dan digunakan ketika membicarakan ilmu sihir, seperti dalam surah Al-Baqarah ayat 102, yaitu:

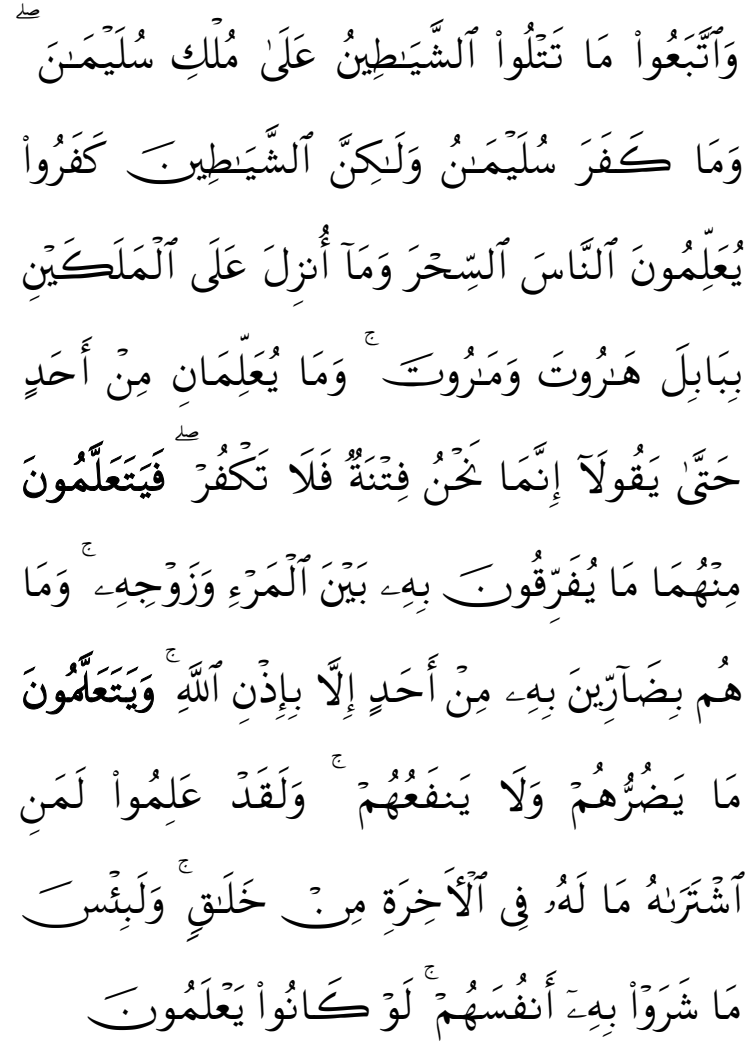

Artinya: Dan mereka mengikuti apa yang dibaca oleh syaitan-syaitan pada masa kerajaan Sulaiman (dan mereka mengatakan bahwa Sulaiman itu mengerjakan sihir), Padahal Sulaiman tidak kafir (tidak mengerjakan sihir), hanya syaitan-syaitan lah yang kafir (mengerjakan sihir). mereka mengajarkan sihir kepada manusia dan apa yang diturunkan kepada dua orang malaikat di negeri Babil Yaitu Harut dan Marut, sedang keduanya tidak mengajarkan (sesuatu) kepada seorangpun sebelum mengatakan: "Sesungguhnya Kami hanya cobaan (bagimu), sebab itu janganlah kamu kafir". Maka mereka mempelajari dari kedua Malaikat itu apa yang dengan sihir itu, mereka dapat menceraikan antara seorang (suami) dengan isterinya. dan mereka itu (ahli sihir) tidak memberi mudharat dengan sihirnya kepada seorangpun, kecuali dengan izin Allah. dan mereka mempelajari sesuatu yang tidak memberi mudharat kepadanya dan tidak memberi manfaat. Demi, Sesungguhnya mereka telah meyakini bahwa Barangsiapa yang menukarnya (kitab Allah) dengan sihir itu, Tiadalah baginya Keuntungan di akhirat, dan Amat jahatlah perbuatan mereka menjual dirinya dengan sihir, kalau mereka mengetahui.

Kata ta'allama di atas berarti belajar. ayat ini dapat dimengerti "bahwa orang-orang Yahudi menerima ilmu sihir dari Harut dan Marut selepas mereka mengajarkannya." Hanya saja dalam konteks Islam, memperoleh ilmu semacam ini tidak ada manfaatnya karena orang yang mempelajarinya cenderung menjadi orang yang sombong seperti yang terjadi pada kaum Yahudi. Oleh karena itu, ilmu sihir dihukumi mudharat mempelajarinya.

Kalimat kedua ta'allama yang disebutkan ayat tersebut menggambarkan bahwa Islam hanya menghendaki ilmu yang bermanfaat, hanya ilmu yang berguna saja yang harus dituntut. Diluar itu ilmu itu akan menjadi bumerang yang pada gilirannya akan menjerumuskan manusia (Yusuf, 2012: 37-39).

Itulah sebab dalam Tafsir Jalalain disebutkan bahwa bagi orang yang menempuh jalan tersebut (sihir) tidak ada 
bagian bagi mereka kebaikan di akhirat, sebab mereka telah menjual kebahagian diri dengan mempelajari ilmu sihir yang akan menjerumuskan diri mereka sendiri. Jika mereka sadar betapa pedihnya siksaan akhirat tentulah mereka tidak mau mempelajarinya (As-Suyuti, 1407: 16). Dengan demikian, belajar dalam Islam tidak hanya memperhatikan sejauh mana ilmu itu bisa dicerap oleh pembelajar, tetapi Islam memandang lebih jauh ke depan, yaitu harus berkaitan dengan ilmu yang memberi manfaat untuk kehidupan di dunia dan akhirat.

Nabi Muhammad saw. pernah bersabda terkait persoalan tersebut:

$$
\text { خَبْرُكْْْ }
$$

Artinya: "Sebaik-baik kamu adalah orang yang mempelajari Al-Qur'an dan mengajarkannya." (H.R. Bukhari).

Hadits tersebut menunjukkan bahwa belajar diistilahkan dengan dan sebaik-baik manusia adalah orang yang belajar Al-Qur'an dan mengajarkannya. Jadi, dari hadits ini semakin memperkuat bahwa belajar objeknya harus hal-hal yang positif. Itulah sebab Al-Qur'an dijadikan sebagai objek yang paling baik untuk dipelajari sebab Al-Qur'an merupakan Kalam Allah yang di dalamnya banyak berbicara tentang nilai-nilai dan prinsipprinsip umum ilmu pengetahuan.
Kemudian jika didalami kembali kata seperti sebelumnya disebut berasal dari kata 'alima yang seakar dengan kata 'alam (dunia) maka kata ini menunjukkan bahwa Al-Qur'an bukan fiksi, tetapi isinya adalah fakta-fakta. Untuk semakin jelasnya Shihab (2008: 427) menekankan bahwa 'ilm dari segi bahasa adalah kejelasan. Setiap kata yang terbentuk dari ' $i l m$ berarti kejelasan seperti kata 'ulmat (bibir sumbing) dan 'alamat (alamat). Kedua kata tersebut menunjukkan sesuatu yang jelas.

Selanjutnya Raghib Al-Ashfahani menyebut bahwa kata al-ta'lim berarti pengajaran atau pemberitahuan, yaitu menggerakkan diri untuk menggambarkan makna-makna. Sementara itu, kata ta'allum berarti belajar mengetahui, perhatian diri untuk menggambarkan makna-makna tersebut. Jadi kata ta'allum mengandung makna al-i'lamu yang berarti pemberitahuan jika pembelajaran itu dilakukan terus menerus (Al-Ashfahani, 2017: 775). Jadi, dalam kata al-ta'lim ini memberikan sinyal bahwa belajar adalah kehendak, dan belajar itu merupakan aktivitas yang berkesinambungan dan sistematis yang pada akhirnya akan mampu memberikan efek pada seseorang dengan memvisualisasikan apa-apa saja yang dipelajari. Dalam bahasa fiqh-nya, 
belajar itu harus mampu melahirkan amal yang baik untuk menuju keridhoan Allah swt.

\section{Hakikat Belajar dalam Istilah Darasa}

Selain ta'allama istilah belajar juga disebut dengan menggunakan istilah darasa yang muncul dalam Al-Qur'an sebanyak 6 kali. Lima dalam bentuk kata kerja (fiil), selebihnya muncul dalam bentuk masdar. Terkait dengan lima kata kerja, masing-masing membentuk fi'il madhi sebanyak dua kali dan tiga kali dalam bentuk fi'il madhori'. Kata yang berbentuk fi'il madhi terhadap dalam surah al-An'am ayat 105; al-A'raf ayat 169. Sementara itu berbentuk fi'il madhori' terdapat dalam surah Ali-Imran ayat 79 dan 80; al-Qalam ayat 34-38 dan Saba' ayat 44.

Untuk sekedar contoh, bagaimana Al-Qur'an menggunakan kata darasa dalam menyebutkan proses belajar mengajar di sini diketengahkan surah alAn'am ayat 105:
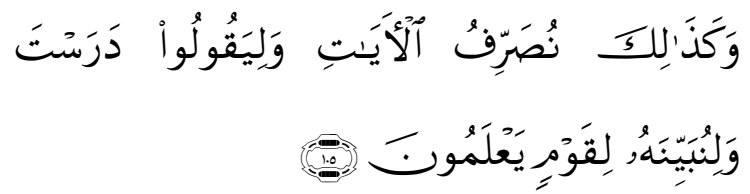

"Demikianlah Kami mengulang-ulangi ayat-ayat Kami supaya (orang-orang yang beriman mendapat petunjuk) dan supaya orang-orang musyrik mengatakan: "Kamu telah mempelajari ayat-ayat itu (dari ahli
Kitab)", dan supaya Kami menjelaskan Al Quran itu kepada orang-orang yang mengetahui".

Istilah dalam ayat di atas terlihat dihubungkan dengan mempelajari kitab. Model semacam ini memberikan makna bahwa Kitab (Al-Qur'an) adalah sumber kehidupan yang dibaca, dipelajari, diamalkan untuk keselamatan dunia dan akhirat. Shihab (2001: 224) menjelaskan kata dalam ayat ini adalah membaca seksama untuk dihafal dan dimengerti. Pengertian ini dapat dipahami belajar merupakan usaha yang melibatkan konsentrasi psikis dan fisik manusia. Sebab secara normatif manusia tidak akan mampu menghafal, memahami, mengerti jika fisik tidak hadir, atau seandainya fisik manusia hadir tanpa adanya pemusatan daya potensi kognitif, tentu mustahil juga manusia bisa memperoleh ilmu pengetahuan.

Sementara menurut AlIsfahani adalah meninggalkan bekas. Seperti terlihat dalam kalimat

, maقِيَ اثرُها ada bekasnya". Dalam contoh yang lain disebutkan

"Aku mempelajari ilmu" bermakna "Saya memperoleh bekasnya dengan menghafal" (Al-Ashfahani, 2017: 223). Jadi, belajar juga dipahami adanya efek dalam diri 
akibat bertambahnya pengetahuan dan pengalaman. Memang idealnya belajar harus demikian. Jika ada perubahan yang terjadi secara spontan, tidaklah semuanya dapat dikategorikan sebagai hasil belajar sebab bekas atau perubahan yang masuk kategori hasil belajar haruslah sesuai dengan prinsip-prinsip belajar itu sendiri. Dalam Islam hasil belajar itu idealnya harus mengacu kepada mendapatkan kemuliaan disisi Allah swt.

Itulah sebabnya dalam Islam belajar harus benar-benar lahir dari sebuah kesadaran tingkat tertinggi. Prinsip seperti ini untuk melepaskan segala hal dari diri manusia yang bersifat khayalan, mitos, takhayul maupun mistis dan lainnya. Jadi perolehan ilmu harus benar-benar sesuai dengan prinsip-prinsip Ilahiyah yang telah meletakkan mitos, takhayul, khayalan panjang yang tidak bermanfaat, mistis dan sejenisnya sebagai capaian menyimpang manusia akibat dari keserakahan yang terlalu banyak menuruti hawa nafsu dan bisikan syaitan.

Dalam hadits Nabi Muhammad saw. sebagaimana diriwayatkan oleh Imam Muslim sebagai berikut:

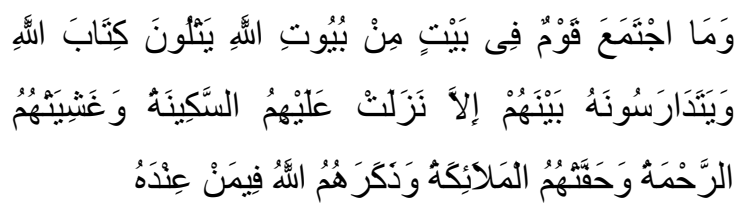
di salah satu rumah Allah membaca Kitabullah dan saling mengajarkan satu dan lainnya melainkan akan turun kepada mereka sakinah (ketenangan), akan dinaungi rahmat, akan dikeliling para malaikat dan Allah akan menyebut-nyebut mereka di sisi makhluk yang dimuliakan di sisi-Nya."

Adapun Kalimat وَيَتَدَارَسُونَهُ بَيَنَهُمْ (dan mereka saling mempelajari di antara mereka) menunjukkan bahwa belajar membutuhkan jiwa besar untuk dapat menghargai orang lain. Berdasarkan hadits tersebut, belajar sering melibatkan orang banyak. Meskipun sesekali tidak melibatkan orang banyak, belajar dalam Islam jauh lebih baik dibimbing oleh seorang guru. Belajar yang tidak disertai dengan guru dari pengertian di atas berdampak menjadi kurang efektif. Memang boleh saja belajar mandiri (otodidak), tapi perlu digarisbawahi, belajar demikian sesuai dengan pemahaman hadits di atas, pelajar tersebut harus tetap pada prinsip dasar, yaitu menghadirkan kesadaran penuh dan jiwa besar untuk mampu mendapatkan bekas atau manfaat dari apa yang dipelajari.

Menarik untuk diperhatikan, dalam sebuah artikel disebutkan pada dasarnya konsep belajar mengajar dengan istilah darasa ini sudah menjadi bahasa populer bagi muslim Indonesia. Muslim Indonesia 
idealnya adalah umat yang punya tradisi belajar excellent. Hal ini dapat dilihat bagaimana umat muslim Indonesia menggunakan istilah dalam percakapan terutama pada bulan suci Ramadhan. Kata berasal dari kata darasa seperti diuraikan sebelumnya. Kemudian istilah mengikuti pola sehingga menjadi

(tadarus). Adapun fi'il yang mengikuti wazan tersebut sering dimaknai dengan yang berarti antara fi'il (subjek) dan $m a f^{\prime} u l$ (objek) sama-sama melakukan perbuatan atau sama-sama aktif dalam proses pembelajaran.

Jadi, pada hakikatnya tadarusan pada bulan Ramadhan haruslah sampai kepada terbentuknya belajar interaktif antara yang membaca Al-Qur'an dan individu yang mendengar bacaan AlQur'an tersebut. Namun praktek tadarusan yang dilakukan di mesjid-mesjid pada bulan Ramadhan terkesan hanya satu arah, di mana seorang membacakan ayat-ayat Al-Qur'an, sedangkan yang lain cenderung hanya menunggu giliran saja. Bahkan yang paling ironis tadarusan hanya dilakukan oleh anak-anak dan remaja yang baru pandai belajar Al-Qur'an, sedangkan orangtua dan para ustadz-ustadz terkesan kurang aktif dalam tadarusan. Oleh karena itu, pemahaman terhadap makna tadarusan tersebut perlu disegarkan kembali agar pesan tadarusan untuk mentadabburi AlQur'an tercapai. Kemudian makna tadarausan juga sangat baik diterapkan dalam proses pembelajaran di lembagalembaga pendidikan Islam.

\section{Hakikat Belajar dalam Istilah Thalaba}

Selain istilah lain yang telah diuraikan, dalam tradisi Islam belajar sering juga dipahami dengan istilah thalaba ( ). Dalam Kamus Bahasa Arab diartikan mencari atau meminta. Kata juga sama dengan istilah hawala akhjahu yaitu berusaha mendapatkannya. Makna lain adalah taba'ada yang bermakna jauh (Munawwir, 1997: 857). Jadi belajar merupakan aktivitas sadar yang lahir dari jiwa dengan cara mencari dan menuntut bukan menunggu, artinya seorang pelajar harus aktif dan agresif dalam hal mencari ilmu dan pengalaman dari guru maupun lingkungannya.

Dalam hadits dijelaskan

Menuntut ilmu wajib atas setiap muslim." (H.R. Ibnu Majah). Kata dalam hadits ini dapat dimaknai dengan meminta atau menuntut, seperti halnya seseorang menuntut sesuatu agar sesuatu itu benar-benar diberikan kepadanya dari orang yang memiliki sesuatu objek. Jadi belajar itu merupakan 
usaha yang menuntut keseriusan agar sesuatu itu dapat berpindah ke dalam jiwa.

Begitu pentingnya untuk memiliki ilmu sehingga ada ungkapan bijak dari ulama yang menyebutkan carilah ilmu sampai ke negeri Cina "Uthlub al-ilma walau bi al-Sin" maknanya "tuntutlah ilmu walau ke negeri Cina.” Penggunaan kata Thalaba disitu menunjukkan bahwa Islam punya semangat belajar tinggi dan visioner sampai-sampai ada ulama menganjurkan penuntut ilmu untuk belajar ke negeri Cina karena negeri itu termasuk negeri dengan kemajuan peradaban yang cukup tua.

Berikutnya pelajaran lain yang dapat diambil dari perkataan bijak di atas adalah belajar dalam Islam tidak terikat ruang dan waktu, serta sangat sportif terhadap eksistensi ilmu pengetahuan. Artinya selama sesuatu itu berhubungan dengan kebenaran dari manapun datangnya, Islam tetap menjadikannya sebagai sumber ilmu pengetahuan yang harus dipelajari.

Ada mahfudhot yang cukup terkenal terutama di kalangan santri, yaitu Unzur maqala wala tanzur man-qala, yaitu lihatlah apa yang dikatakan jangan lihat siapa yang mengatakan. Hal ini menunjukkan bahwa seorang penuntut ilmu tidak boleh menutup mata dari sebuah kebenaran walaupun datangnya bukan dari sumber yang diharapkan. Cuma persoalan ini haruslah tetap digarisbawahi bahwa sebaik-sebaik sumber kebenaran adalah dari yang Maha Haq, bukan dari yang bathil. Artinya mencari ilmu dari yang bukan sumber utamanya boleh-boleh saja tanpa harus menafikan sumber utama dalam Islam. Itulah sebabnya Islam disebut agama yang sangat toleran, walaupun kebenaran itu datang dari subjek yang bathil, seorang muslim tetap harus mempertimbangkan makna-makna yang datang dari yang batil tanpa harus mengikuti kebatilan yang terdapat dalam diri personalnya.

Kemudian menurut Al-Ashfhani dalam kitabnya, kata malah didefinisikan lebih komprehensif bahwa bermakna menggali keberadaan sesuatu, baik dalam bentuk fisik maupun non fisik (Al-Ashfahani, 2017: 587). Bila belajar dituntut untuk mendalami yang fisik maupun yang non fisik maka hal ini sangat sejalan dengan pesan Allah Swt. dalam surah Al-Kahfi ayat 78, yaitu:

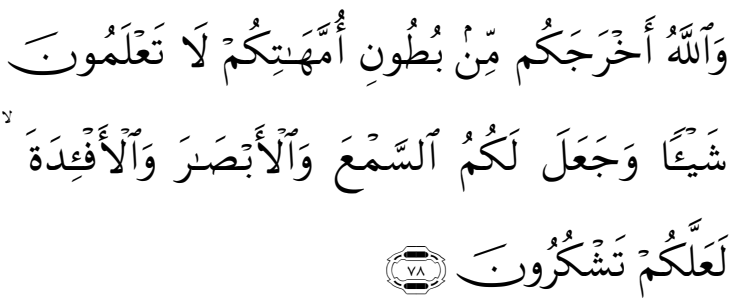

Artinya: "Dan Allah mengeluarkan kamu dari perut ibumu dalam Keadaan tidak mengetahui sesuatupun, dan Dia memberi 
kamu pendengaran, penglihatan dan hati, agar kamu bersyukur".

Dalam ayat ini potensi belajar yang dianugerahkan Allah Swt. kepada manusia meliputi aspek fisik dan non fisik atau psikis. Adapun aspek yang fisik yang terdapat dalam diri manusia terdiri dari assam'a "pendengaran", al-abshar “penglihatan”, dan aspek psikisnya adalah al-afidah "hati" dan al-'aql "akal" yang disebut sebanyak 49 kali dalam Al-Qur'an dengan segala bentuk derivasinya.

Hal ini menunjukkan bahwa seorang pelajar selain berupaya keras untuk mencarinya, pelajar juga harus memperhatikan objek-objek yang dipelajari sampai benar-benar terkuak subtansi darinya. Dengan demikian, belajar dalam Islam bukanlah bersenda gurau belaka, tetapi belajar membutuhkan itikad, konsentrasi, dan keseriusan. AlQur'an sendiri beberapa kali memakai istilah ini, seperti dalam Q.S. AlKahfi ayat 41:

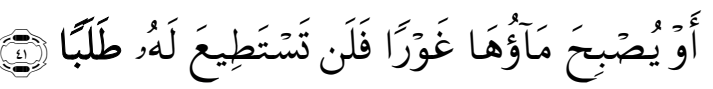

Artinya: "Atau airnya menjadi surut ke dalam tanah, Maka sekali-kali kamu tidak dapat menemukannya lagi".

Kemudian surah Al-Hajj ayat 73, Allah Swt. menggunakan asal kata ketika menyebut yang menyembah dan yang disembah.

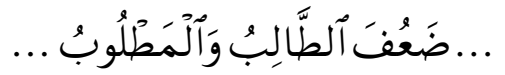

Artinya: "Amat lemahlah yang menyembah dan Amat lemah (pulalah) yang disembah."

Berdasarkan dua ayat tersebut AlAshfahani memberi komentar bahwa kalimat athlabtu fulanan bermakna aku segera membantunya. Kalimat athlaba alkalaau dapat dipahami memperlambat dalam memberikan pertolongan, hal ini dilakukan sampai dia benar-benar minta tolong (Al-Ashfahani, 2017: 586). Jadi, semakin jelas bahwa belajar memiliki indikasi ada yang minta tolong ada yang menolong, ada yang minta diberi dan ada yang memberi. Namun posisi pemberi dalam hal ini guru tidak sekali-kali memberinya kecuali yang minta diberi (pelajar) itu benar-benar memintanya.

Guru juga tidak dibenarkan memberikan ilmu jika peserta didik tidak membutuhkannya. Jadi, kesiapan dan kebutuhan peserta didik menjadi penting untuk diperhatikan karena keduanya sangat menentukan berhasil tidaknya pembelajaran yang dilakukan. Jika demikian berarti guru memiliki peran yang sangat penting dalam proses pembelajaran. Guru sangat disarankan mampu mengidentifikasi karakteristik dan kebutuhan peserta didik, serta mampu 
menggunakan berbagai pendekatan dan metode sehingga pembelajaran yang dilakukan efektif dan efisien dalam mencapai tujuan pembelajaran (Tambak, 2016: 30).

Sementara itu, kedudukan peserta didik dituntut untuk membuktikan kepada guru bahwa dirinya benar-benar ikhlas dan tulus, serta membutuhkan ilmu untuk dipelajari. Pembuktian peserta didik tentang kebutuhannya terhadap belajar tentu menjadi bahan bagi guru untuk mengambil keputusan yang terbaik. Itulah sebabnya Nabi Muhammad saw. bersabda:

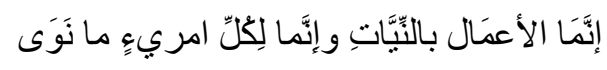

Artinya: "Sesungguhnya perbuatan itu tergantung dengan niatnya, dan setiap orang akan mendapat sesuai apa yang diniatkannya." (H.R. Bukhari dan Muslim).

Jika niat menentukan apa yang didapatkan sesudahnya maka tidak berlebihan jika hadits tersebut dipahami sebagai isyarat bahwa belajar idealnya harus dimulai dengan niat berupa perencanaan yang matang. Argumentasi ini sangat beralasan sebab keberhasilan sesungguhnya berawal dari matangnya sebuah proses perencanaan. Tidak mungkin proses bisa matang jika tidak ada kajian, perhatian, motivasi yang mendalam. Dengan demikian belajar dalam Islam termasuk aktivitas yang lahir dari sebuah kesadaran.

\section{SIMPULAN}

Berdasarkan studi kepustakaan yang dilakukan maka dapat ditarik simpulan bahwa belajar dalam Islam terdapat pada tiga istilah yaitu, ta'allama, darasa, dan thalaba. Ketiga istilah ini menunjukkan bahwa belajar berarti meninggalkan bekas atau efek. Adapun bekas hasil belajar tersebut merupakan akses dari proses yang dilakukan. Proses belajar dalam pendidikan Islam penting sehingga setiap peserta didik harus memperhatikan konten pembelajarannya. Kemudian pendidikan Islam menilai belajar harus dipandu oleh guru yang memahami kondisi kepribadian pelajar. Tidak dibenarkan jika guru memberi pelajaran bagi peserta didik yang tidak memiliki kesiapan. Selain itu belajar dalam Islam harus dilakukan secara berkesinambungan dan sengaja melibatkan kesiapan fisik dan psikis. Dalam proses belajar itu harus didahului oleh perencanaan yang matang dan sistematis. Dengan demikian, hasil belajar pun akan memberi bekas yang dapat ditinjau ulang sewaktu-waktu ketika dibutuhkan. Jadi, orientasi terakhir belajar dalam Islam 
adalah perubahan ke arah yang lebih baik

sesuai dengan tuntutan Allah swt.

\section{DAFTAR PUSTAKA}

Al-Asfahani, A. (tt). Al-Mufradat $f i$ Gharib al-Qur'an, Jilid 2, Damsyiq: Dar al-Nasyir.

Al-Ashfahani, A. (2017). Al-Mufradat $f i$ Gharib al-Qur'an, terj. Ahmad Zaini Dahlan, Jilid 2, Depok: Pustaka Khazanah Fawa'id.

Al-Mahalli, J., dan As-Suyuti, J. (1407 Hijriyah). Tafsir al-Imamaini alJalalain, Damsyiq: Dar Ibn Katsir.

A.W., Munawwir. (1997). Kamus AlMunawwir. Surabaya: Pustaka Progresif.

Barni, M. (2011). Pendidikan Perspektif Al-Qur'an (Studi Al-Qur'an Tentang Pendidikan. Yogyakarta: Pustaka Prisma.

Erriyanto. (2015). Analisis Isi: Pengantar Metodologi Untuk Penelitian Ilmu Komunikasi dan Ilmu-Ilmu Sosial Lainnya. Jakarta: Pranadamedia Group.

Gasong, D., (2018). Belajar dan Pembelajaran. Yogyakarta: Deepublish.

Harahap, M., \& Siregar, L. M. (2017). Konsep Pendidikan Islam Dalam Membentuk Manusia Paripurna. Jurnal Pendidikan Agama Islam Al-Thariqah, 2(2), 148-163.

Kosim, M. (2008). Ilmu Pengetahuan Dalam Islam (Perspektif FilosofisHistoris). Tadris: Jurnal Pendidikan Islam, 3(2), 121-140.

Muhsin, A. (2012). Potensi Pembelajaran Fisik Dan Psikis Dalam Al-Qur'an Surat An-Nahl: 78 (Kajian Tafsir
Pendidikan Islam). Prosiding Seminas, 1(2). 1-4.

Pane, A., \& Dasopang, M.D. (2017). Belajar dan pembelajaran. Fitrah: Jurnal Kajian Ilmu-Ilmu Keislaman, 3(2), 333-352.

Shihab, M.Q. (2008). Wawasan Al-Qur'an Tafsir Maudhu'i Atas Pelbagai Persoalan Umat. Bandung: Mizan.

Susanti, R. (2018). Analisa Komponen Makna Kata Sinonim dalam Bahasa Arab. Al-Af'idah: Jurnal Pendidikan Bahasa Arab dan Pengajarannya, 2(1), 89-107.

Tambak, S. (2016). Metode Resitasi dalam Pembelajaran Pendidikan Agama Islam. Al-Hikmah: Jurnal Agama dan Ilmu Pengetahuan, 13(1), 30-51.

Wahyuningsih, S. (2014). Implementasi Sistem Pendidikan Islam Pada Masa Daulah Abbasiyah Dan Pada Masa Sekarang. Jurnal Kependidikan, 2(2), 109-126.

Yusuf, K.M. (2012). Tafsir Tarbawi, Pekanbaru: Zanafa Publishing.

Zed, M. (2008). Metode Penelitian Kepustakaan. Jakarta: Yayasan Obor Indonesia. 